\title{
Chemical composition analysis on industrial scale ingots and castings of TiAl alloys
}

\author{
${ }^{*}$ Xian-fei Ding ${ }^{1,2,3,4}$, Yi-qun Zhao ${ }^{1,2,3}$, Jia-bin Zuo ${ }^{1,2,3}$, Xin Feng ${ }^{1,2,3}$, Hai Nan', 2, ${ }^{\text {, Yong-feng Liang }}{ }^{4}$, Yan-qing Su \\ 1. Cast Titanium Alloy R\&D Center, Beijing Institute of Aeronautical Materials, Beijing 100095, China \\ 2. Beijing Engineering Research Center of Advanced Titanium Alloy Precision Forming Technology, Beijing 100095, China \\ 3. BAIMTEC Material Co., Ltd., Beijing 100094, China \\ 4. State Key Laboratory for Advanced Metals and Materials, University of Science and Technology Beijing, Beijing 100083, China \\ 5. National Key Laboratory for Precision Hot Processing of Metals, Harbin Institute of Technology Harbin, Harbin 150001, China
}

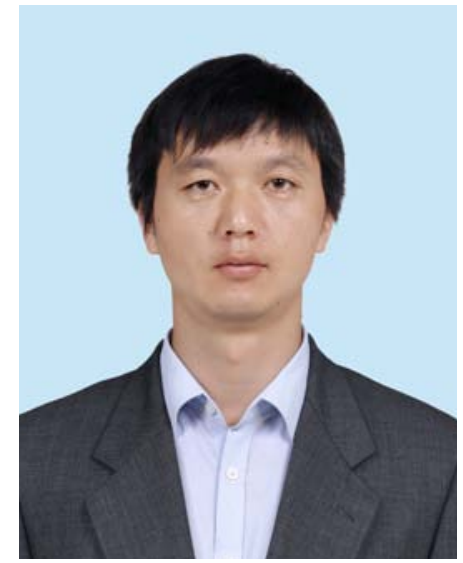

*Xian-fei Ding

Born in 1980, Senior Engineer, Ph.D. His research interests mainly focus on cast titanium alloys, Ti-Al intermetallics and their forming technologies.

E-mail: xianfeimail@gmail.com

Received: 2020-06-23

Accepted: 2020-09-27

\begin{abstract}
The chemical composition variation of the TiAl-4722 alloys was examined in a batch of the industrial scale master ingots, and in the corresponding castings prepared by conventional vacuum arc remelting (VAR) combined with induction skull melting (ISM) and investment casting processes. The content changes of major elements and interstitial elements were evaluated based on the chemical analysis at the top and bottom of the ingots and castings. Results show that the contents of $\mathrm{C}, \mathrm{N}, \mathrm{H}, \mathrm{Fe}$ and $\mathrm{Si}$ have almost no change in the ingots and castings, suggesting that the chemical analysis on these elements can be based on the batch analysis. The $\mathrm{O}$ content keeps almost the same in different ingots, but exhibits relatively large differences in castings, which was probably influenced by the reaction between the shell mold and the molten alloy, and the spalling of face coat of the shell mold during casting. For the major elements of $\mathrm{Al}, \mathrm{Nb}$ and $\mathrm{Cr}$, the composition difference between the top and the bottom of the ingots is less than that of the castings. But for the $\mathrm{O}$ element, the trend is different, especially for the castings, suggesting that the investment casting is a homogenization process for $\mathrm{Cr}$ and $\mathrm{Nb}$, but a differentiation process for $\mathrm{O}$. The contents of major elements in castings fluctuate mainly in the same range as that in the ingots, indicating that the contents of the major elements are controllable during investment casting.
\end{abstract}

Key words: TiAl alloys; melting; casting; chemical composition; casting ingot

CLC numbers: TG146.23; Document code: A; Article ID: 1672-6421 2020)06-441-06

$\mathrm{T}$ iAl alloys have great potential applications in aerospace field because of their low density, excellent high-temperature strength and good creep resistance ${ }^{[1-3]}$. Investment casting has been identified as one of the most cost-effective routes for producing TiAl-based components such as turbine blades and turbocharger wheels ${ }^{[4,5]}$. This technology offers the opportunity of producing near-net shape cast TiAl alloy components, and consequently, has received special attention in recent years. Since the properties of the TiAl intermetallic compounds are sensitive to alloying composition, the chemical composition control during the ingot melting and casting process of these alloys is very important to the final casting performance ${ }^{[5-8]}$.

For the industrial scale ingot preparation and casting production, the conventional melting process such as induction skull melting (ISM) combined with vacuum arc remelting (VAR) is an usual way to prevent inclusion and contamination for melting and casting the highly reactive TiAl alloys ${ }^{[9,10]}$. The chemical composition consistence in batches of ingots or castings is very important for the uniformity of properties in the cast components. Significant reduction in unqualified product rate could be achieved if the chemical composition variation in batches of ingots and castings can be controlled, resulting in an improvement in the quality stability of castings ${ }^{[3,11-13]}$.

The aim of present work is to examine the chemical composition variation in a batch of 
master ingots and castings of the TiAl-4722 alloys in industrial scale using conventional VAR combined ISM melting and investment casting processes. For that, the content changes of major elements $(\mathrm{Al}, \mathrm{Nb}$ and $\mathrm{Cr})$ and interstitial elements $(\mathrm{O}, \mathrm{C}, \mathrm{N}$, $\mathrm{H})$ were evaluated based on the chemical analysis on the top and the bottom of the ingots and castings during the present research.

\section{Experimental procedure}

In this work, pure $\mathrm{Ti}$ (99.96wt.\%), pure Al (99.99wt.\%), pure $\mathrm{Cr}(99.99 w \mathrm{w} . \%)$ and $\mathrm{Al}-\mathrm{Nb}(99.97 \%, \mathrm{Nb}: 75 \mathrm{wt} \%)$ master alloys were used as the raw materials, and a batch of master ingots with diameter of $280 \mathrm{~mm}$ and height of $500 \mathrm{~mm}$ were prepared by VAR + ISM + VAR under high-vacuum atmosphere. Metal mold was used during the ISM process. After removing the surface layer, the as-received master ingots were separately remelted in a cold crucible induction furnace under high purity argon atmosphere and then poured into a roasted $\mathrm{Y}_{2} \mathrm{O}_{3}$ shell mold in a top pouring way during investment casting. In total, 10 TiAl-4722 alloy master ingots, namely from No. 1 to No. 10, were prepared, and subsequently cast into 10 batches of corresponding blade-shaped castings with a height of $300 \mathrm{~mm}$. The specimens for chemical composition analysis were cut at the positions $10 \mathrm{~mm}$ from the top and from the bottom of the master ingots and the corresponding castings. The $\mathrm{Al}, \mathrm{Nb}$ and $\mathrm{Cr}$ contents were determined using spectrometric analysis. The $\mathrm{C}, \mathrm{N}, \mathrm{H}$ and $\mathrm{O}$ contents were detected using the infrared absorption spectrometry, and the $\mathrm{Fe}$ and Si contents were detected using inductively coupled plasma atomic emission spectrometry.

\section{Results and discussion}

Tables 1 and 2 list the chemical compositions at the top and the bottom of the ingots, respectively. As shown in Table 1, the variation ranges of the $\mathrm{Al}, \mathrm{Nb}$ and $\mathrm{Cr}$ contents are $31.7 \mathrm{wt} . \%$ 32.6 wt. $\%, 4.80$ wt. $\%-4.87$ wt. $\%$ and 2.58 wt. $\%-2.70$ wt.\% at the top of the experimental ingots, respectively, and $31.2 \mathrm{wt} . \%$ $32.5 w t . \%, 4.78 w t . \%-4.98 w t . \%$ and $2.56 w t . \%-2.72 w t . \%$ at the bottom. The overall variation of major element contents at the bottom of the ingots is slightly higher than that at the top. The $\mathrm{O}$ content of all the ingots can be controlled below $600 \mathrm{ppm}$, except for the one at the top of No. 1 ingot. The highest contents of $\mathrm{N}$ and $\mathrm{H}$ can reach $120 \mathrm{ppm}$ and $12 \mathrm{ppm}$, respectively. The contents of impurity elements Fe and Si keep almost the same in different parts of the ingots.

Table 1: Chemical composition at the top of the experimental ingots (wt.\%)

\begin{tabular}{|c|c|c|c|c|c|c|c|c|c|}
\hline No. & Al & Nb & $\mathrm{Cr}$ & C & 0 & $\mathbf{N}$ & $\mathrm{H}$ & $\mathrm{Fe}$ & Si \\
\hline 1 & 32.6 & 4.87 & 2.70 & 0.010 & 0.080 & 0.010 & 0.0007 & 0.05 & 0.02 \\
\hline 2 & 31.8 & 4.86 & 2.62 & 0.008 & 0.052 & 0.012 & 0.0011 & 0.05 & 0.02 \\
\hline 3 & 31.9 & 4.87 & 2.66 & 0.012 & 0.054 & 0.012 & 0.0008 & 0.05 & 0.02 \\
\hline 4 & 32.0 & 4.86 & 2.62 & 0.008 & 0.054 & 0.010 & 0.0010 & 0.05 & 0.02 \\
\hline 5 & 32.0 & 4.90 & 2.66 & 0.008 & 0.052 & 0.010 & 0.0010 & 0.05 & 0.02 \\
\hline 6 & 32.6 & 4.89 & 2.67 & 0.008 & 0.052 & 0.010 & 0.0006 & 0.05 & 0.02 \\
\hline 7 & 31.7 & 4.80 & 2.62 & 0.007 & 0.056 & 0.012 & 0.0010 & 0.05 & 0.02 \\
\hline 8 & 32.0 & 4.80 & 2.58 & 0.008 & 0.052 & 0.010 & 0.0008 & 0.05 & 0.02 \\
\hline 9 & 31.9 & 4.86 & 2.60 & 0.008 & 0.053 & 0.011 & 0.0007 & 0.05 & 0.02 \\
\hline 10 & 32.0 & 4.81 & 2.61 & 0.009 & 0.057 & 0.012 & 0.0007 & 0.05 & 0.02 \\
\hline Average & 32.05 & 4.852 & 2.634 & 0.0086 & 0.0562 & 0.0109 & 0.00084 & 0.05 & 0.02 \\
\hline $\begin{array}{l}\text { Standard } \\
\text { deviation }\end{array}$ & 0.306 & 0.036 & 0.037 & 0.0014 & 0.0085 & 0.0010 & 0.00017 & 0 & 0 \\
\hline
\end{tabular}

Tables 3 and 4 list the chemical compositions at the top and the bottom of the castings, respectively. It can be seen that the variation ranges of the $\mathrm{Al}, \mathrm{Nb}$ and $\mathrm{Cr}$ element contents are $31.2 \mathrm{wt} . \%-32.7 \mathrm{wt} . \%, 4.82 \mathrm{wt} . \%-4.92 \mathrm{wt} . \%$ and $2.54 \mathrm{wt} . \%-$ $2.68 \mathrm{wt} . \%$ at the top of the castings, respectively, and $31.0 \mathrm{wt} . \%-$ 32.6 wt. $\%$, 4.83wt.\%-4.92wt.\% and 2.54wt. $\%-2.68 w t . \%$ at the bottom. The major element contents do not vary significantly at the top and the bottom of the castings. The $\mathrm{O}$ contents in castings are slightly higher than that in the ingots. The contents of other interstitial elements and the impurity elements have almost no change for the castings. Since the contents of C, N, $\mathrm{H}, \mathrm{Fe}$ and $\mathrm{Si}$ remain almost unchanged in different ingots and castings, the chemical analysis on these elements can be based on the batch analysis.

Figure 1 shows the average $\mathrm{Al}, \mathrm{Cr}, \mathrm{Nb}$ and $\mathrm{O}$ contents at the top and the bottom of the experimental ingots/castings. As shown in Fig. 1(a), the average $\mathrm{Al}$ content at the top of both ingots and castings is a little higher than that at the bottom, 
Table 2: Chemical composition at the bottom of the experimental ingots (wt.\%)

\begin{tabular}{|c|c|c|c|c|c|c|c|c|c|}
\hline No. & Al & $\mathrm{Nb}$ & $\mathrm{Cr}$ & C & 0 & $\mathbf{N}$ & $\mathrm{H}$ & $\mathrm{Fe}$ & Si \\
\hline 1 & 32.5 & 4.90 & 2.72 & 0.008 & 0.046 & 0.009 & 0.0005 & 0.05 & 0.02 \\
\hline 2 & 31.2 & 4.78 & 2.56 & 0.008 & 0.049 & 0.010 & 0.0010 & 0.05 & 0.02 \\
\hline 3 & 31.6 & 4.90 & 2.60 & 0.010 & 0.054 & 0.011 & 0.0012 & 0.05 & 0.02 \\
\hline 4 & 31.7 & 4.83 & 2.60 & 0.008 & 0.050 & 0.010 & 0.0007 & 0.05 & 0.02 \\
\hline 5 & 31.4 & 4.86 & 2.59 & 0.008 & 0.050 & 0.010 & 0.0010 & 0.05 & 0.02 \\
\hline 6 & 32.4 & 4.98 & 2.65 & 0.008 & 0.050 & 0.010 & 0.0009 & 0.05 & 0.02 \\
\hline 7 & 31.7 & 4.82 & 2.59 & 0.008 & 0.055 & 0.010 & 0.0010 & 0.07 & 0.02 \\
\hline 8 & 31.4 & 4.84 & 2.58 & 0.008 & 0.056 & 0.011 & 0.0010 & 0.05 & 0.02 \\
\hline 9 & 32.2 & 4.88 & 2.64 & 0.008 & 0.056 & 0.011 & 0.0009 & 0.05 & 0.02 \\
\hline 10 & 32.2 & 4.86 & 2.60 & 0.008 & 0.056 & 0.011 & 0.0012 & 0.05 & 0.02 \\
\hline Average & 31.83 & 4.865 & 2.613 & 0.0082 & 0.0522 & 0.0103 & 0.00092 & 0.052 & 0.02 \\
\hline $\begin{array}{l}\text { Standard } \\
\text { deviation }\end{array}$ & 0.46 & 0.055 & 0.046 & 0.0006 & 0.0036 & 0.0007 & 0.00024 & 0.006 & 0 \\
\hline
\end{tabular}

Table 3: Chemical composition at the top of the experimental castings (wt.\%)

\begin{tabular}{|c|c|c|c|c|c|c|c|c|c|}
\hline No. & Al & Nb & $\mathrm{Cr}$ & C & 0 & $\mathbf{N}$ & H & $\mathrm{Fe}$ & Si \\
\hline 2 & 31.9 & 4.88 & 2.66 & 0.006 & 0.069 & 0.010 & 0.0014 & 0.05 & 0.02 \\
\hline 3 & 31.8 & 4.82 & 2.61 & 0.008 & 0.056 & 0.012 & 0.0006 & 0.05 & 0.02 \\
\hline 4 & 31.2 & 4.86 & 2.54 & 0.006 & 0.048 & 0.012 & 0.0012 & 0.05 & 0.03 \\
\hline 5 & 32.1 & 4.86 & 2.66 & 0.006 & 0.067 & 0.012 & 0.0007 & 0.05 & 0.02 \\
\hline 6 & 32.2 & 4.88 & 2.64 & 0.006 & 0.054 & 0.011 & 0.0006 & 0.05 & 0.02 \\
\hline 8 & 32.0 & 4.86 & 2.60 & 0.007 & 0.084 & 0.010 & 0.0008 & 0.05 & 0.03 \\
\hline 9 & 32.7 & 4.92 & 2.68 & 0.010 & 0.074 & 0.009 & 0.0010 & 0.05 & 0.03 \\
\hline Average & 31.99 & 4.869 & 2.627 & 0.0065 & 0.0646 & 0.0109 & 0.0009 & 0.05 & 0.024 \\
\hline $\begin{array}{l}\text { Standard } \\
\text { deviation }\end{array}$ & 0.453 & 0.0302 & 0.0479 & 0.00084 & 0.01259 & 0.00121 & 0.00031 & 0 & 0.005 \\
\hline
\end{tabular}

Table 4: Chemical composition at the bottom of the experimental castings (wt.\%)

\begin{tabular}{|c|c|c|c|c|c|c|c|c|c|}
\hline No. & Al & $\mathrm{Nb}$ & $\mathrm{Cr}$ & C & 0 & $\mathbf{N}$ & $\mathrm{H}$ & $\mathrm{Fe}$ & Si \\
\hline 2 & 31.8 & 4.88 & 2.66 & 0.006 & 0.046 & 0.009 & 0.0018 & 0.05 & 0.02 \\
\hline 3 & 31.8 & 4.83 & 2.62 & 0.006 & 0.082 & 0.014 & 0.0015 & 0.05 & 0.02 \\
\hline 4 & 31.0 & 4.84 & 2.54 & 0.007 & 0.083 & 0.012 & 0.0012 & 0.05 & 0.03 \\
\hline 5 & 31.8 & 4.86 & 2.66 & 0.006 & 0.102 & 0.011 & 0.0009 & 0.05 & 0.02 \\
\hline 6 & 32.0 & 4.89 & 2.64 & 0.006 & 0.044 & 0.012 & 0.0008 & 0.05 & 0.02 \\
\hline 8 & 31.8 & 4.85 & 2.58 & 0.006 & 0.046 & 0.011 & 0.0010 & 0.05 & 0.02 \\
\hline 9 & 32.6 & 4.92 & 2.68 & 0.010 & 0.043 & 0.010 & 0.0006 & 0.05 & 0.02 \\
\hline Average & 31.83 & 4.867 & 2.626 & 0.0062 & 0.0637 & 0.0113 & 0.00111 & 0.05 & 0.021 \\
\hline $\begin{array}{l}\text { Standard } \\
\text { deviation }\end{array}$ & 0.47 & 0.031 & 0.050 & 0.0004 & 0.0246 & 0.0016 & 0.00042 & 0 & 0.004 \\
\hline
\end{tabular}


probably due to the low density floating accumulation in the molten pool during melting and subsequent solidification. From the bottom to the top portion, the average Al content increases by $0.22 \mathrm{wt} . \%$ for the ingots, and $0.16 \mathrm{wt} . \%$ for the castings. The standard deviation of the Al content in the castings is approximately $0.46 \mathrm{wt} . \%$, close to that in the ingots, suggesting that the melting process is controllable for the $\mathrm{Al}$ content. The average $\mathrm{Cr}$ and $\mathrm{Nb}$ contents at the top and the bottom of the experimental ingots and castings are shown in Figs. 1(b) and (c), and clearly, the average content change is noticeable in ingots between the top and the bottom, but not in castings. The standard deviation of the average $\mathrm{Nb}$ or $\mathrm{Cr}$ content remains relatively the same at different locations of the castings ${ }^{[14,15]}$. For the $\mathrm{O}$ element, as indicated in Fig. 1(d), the average content is slightly lower at the bottom of the ingots. While in castings, although the average $\mathrm{O}$ content keeps the same, the standard deviation is distinctly greater at the bottom.

Figure 2 shows the content variations of $\mathrm{Al}, \mathrm{Cr}, \mathrm{Nb}$ and $\mathrm{O}$ at (a)

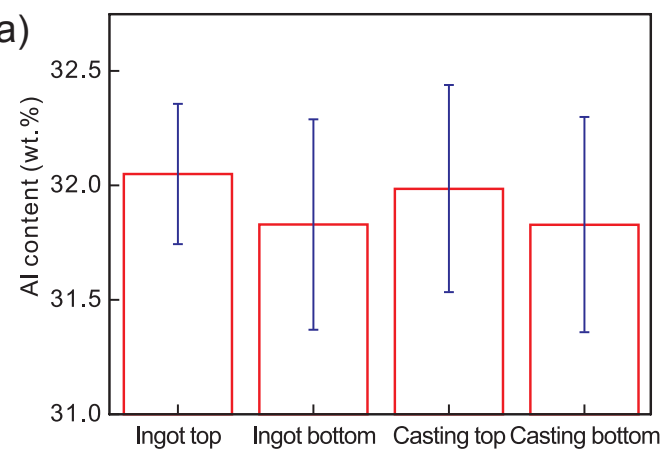

(c)

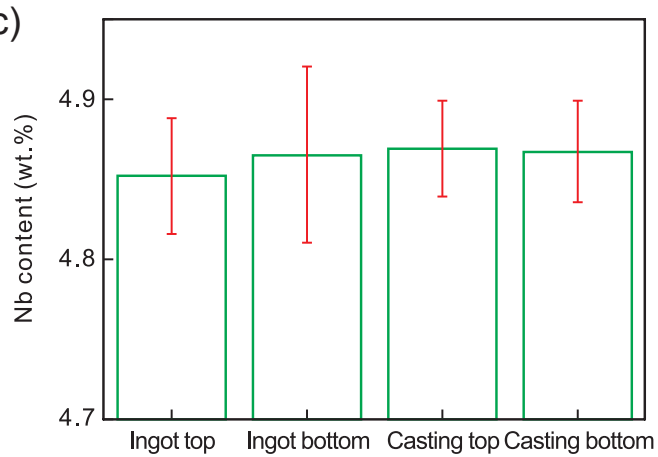

(b)

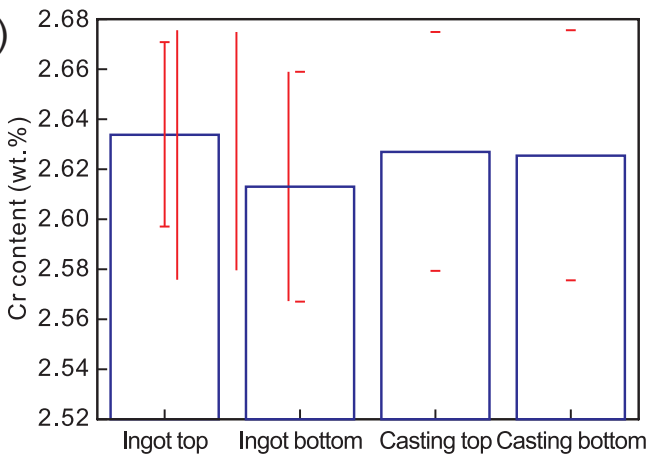

(d)

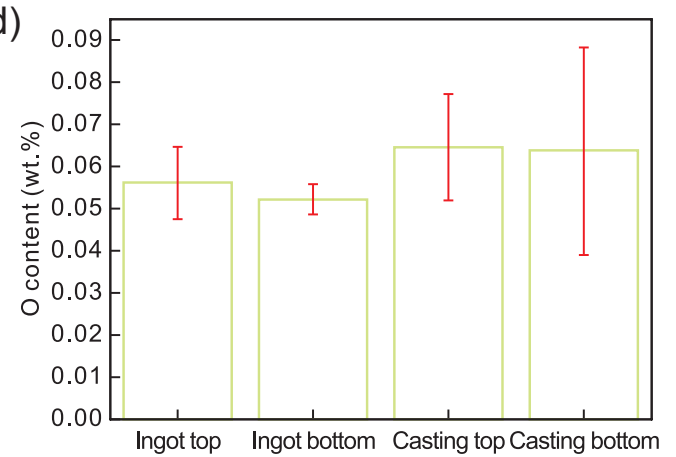

Fig. 1: Average $\mathrm{Al}(\mathrm{a}), \mathrm{Cr}$ (b), $\mathrm{Nb}$ (c) and $\mathrm{O}$ (d) content at the top and bottom of the experimental ingots/castings

the top and bottom of the experimental ingots/castings. As shown in Fig. 2(a), the variation trend of $\mathrm{Al}$ content at the top is in consistent with that at the bottom of both the ingots and castings. The Al content variation of different ingots and castings is much greater than that in different locations of each individual ingot and casting, suggesting that the effect of melting process on $\mathrm{Al}$ content for different ingots/castings is much greater than different locations in single ingot and casting. Compared to the $\mathrm{Al}$ content variation, the variations of both $\mathrm{Cr}$ and $\mathrm{Nb}$ contents are much smaller in both the ingots and castings, as shown in Figs. 2(b) and (c). The content variation of major elements ( $\mathrm{Al}, \mathrm{Nb}$ and $\mathrm{Cr}$ ) in castings is mainly in the range of the corresponding ingots, which indicates that the investment casting process is controllable for the major element content ${ }^{[16]}$. The major element contents in a few castings are higher than that in the corresponding ingots, possibly caused by detecting error or the sampling position effect for the industrial scale products. As shown in Fig. 2(d), the fluctuation of the $\mathrm{O}$ content is small in ingots, but relatively large in castings. Occasionally, the $\mathrm{O}$ content in some castings is slightly lower than that of the corresponding ingots, probably due to oxide inclusion caused by $\mathrm{O}$ accumulation in the ingots.

Figure 3 shows the content differences of $\mathrm{Al}, \mathrm{Cr}, \mathrm{Nb}$ and $\mathrm{O}$ in each ingot and casting. As shown in Fig. 3(a), for the Al content, the value difference between the top and bottom of the castings is less than that of the ingots, and the variation range of castings is close to the ingots, suggesting that the $\mathrm{Al}$ volatilization can be controlled during melting and casting. It should be noted that the $\mathrm{Al}$ content difference in each casting is almost a positive value, possibly caused by the low density floating accumulation during casting. For the $\mathrm{Cr}$ and $\mathrm{Nb}$ elements, as shown in Figs. 3(b) and (c), the difference of the average content is less than $0.08 \%$ in the ingots, and $0.02 \%$ in the castings. For the most part, the $\mathrm{O}$ content difference has almost no change among ingots, and the difference is close to zero in each ingot, but reaches near $\pm 400 \mathrm{ppm}$ in each casting, as shown in Fig. 3(d). It can be speculated that the investment casting is a homogenization process for $\mathrm{Cr}$ and $\mathrm{Nb}$, but a differentiation process for $\mathrm{O}$, which probably caused by the reaction between the shell mold and the molten alloy, and the spalling of face coat shell during casting ${ }^{[17]}$. 

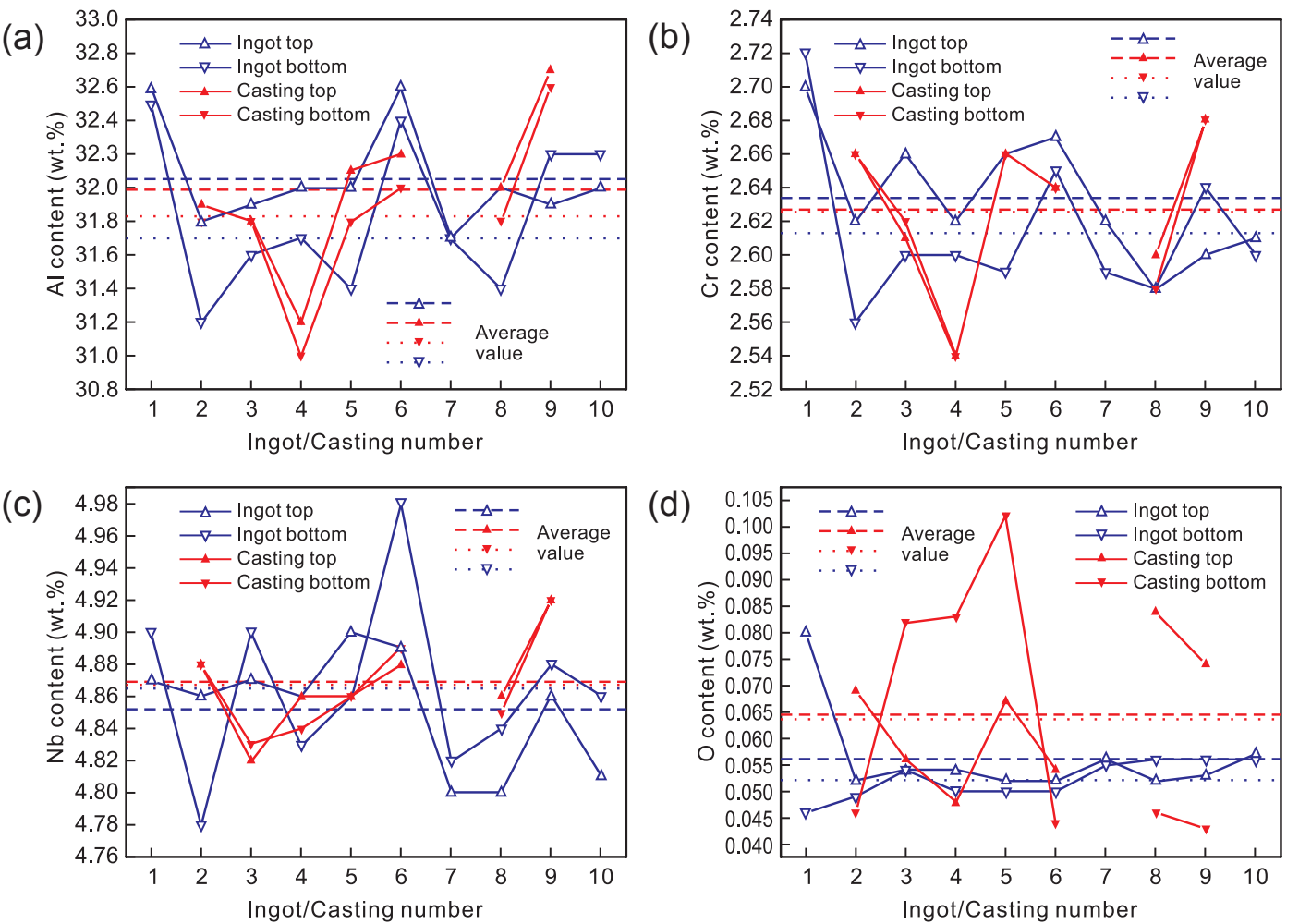

Fig. 2: $\mathrm{Al} \mathrm{(a),} \mathrm{Cr}(\mathrm{b}), \mathrm{Nb}$ (c) and $\mathrm{O}$ (d) content variations at the top and bottom of the experimental ingots/ castings, the dotted lines are the average values

(a)

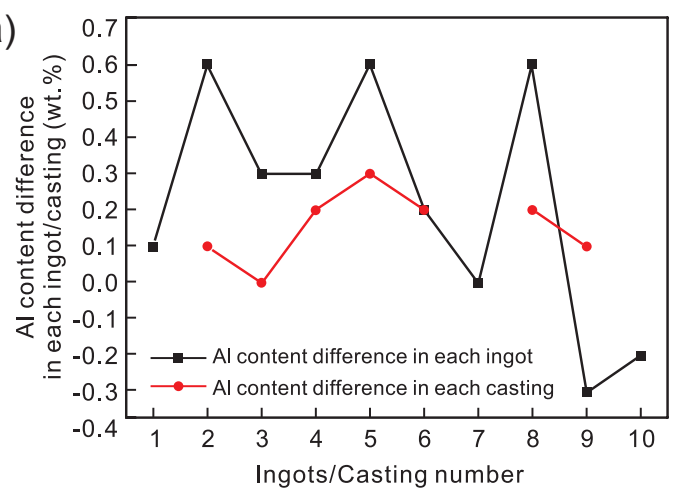

(c)

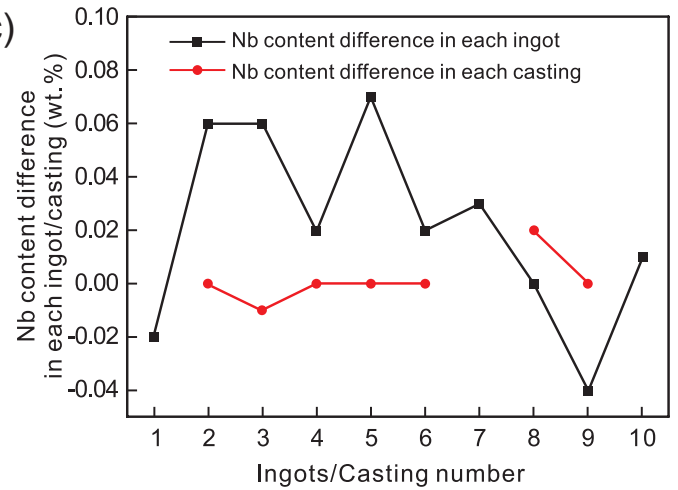

(b)

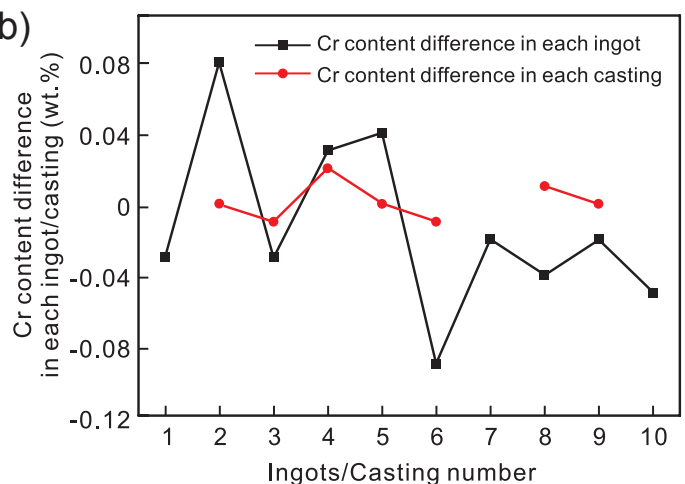

(d)

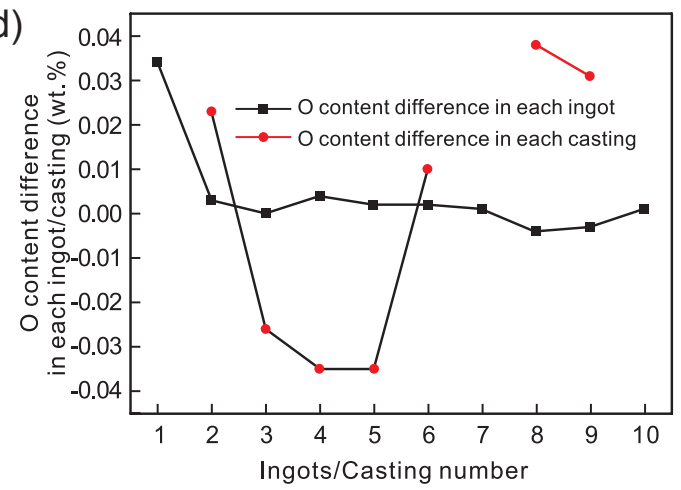

Fig. 3: Content differences of $\mathrm{Al}(\mathrm{a}), \mathrm{Cr}(\mathrm{b}), \mathrm{Nb}$ (c) and $\mathrm{O}$ (d) in each ingot/casting, where the content difference calculated by the content at top minus that at bottom

\section{Conclusions}

In this work, the chemical composition variation was examined in a batch of master ingots and the corresponding castings of
TiAl-4722 alloys for the melting and casting process evaluation. The following conclusions can be drawn from the present results:

(1) The contents of C, N, H, Fe and Si have almost no change 
in ingots and castings, suggesting that the chemical analysis on these elements can be based on the batch analysis.

(2) The $\mathrm{O}$ content in different ingots is homogeneous, but has a big difference in castings, probably influenced by the reaction between the shell mold and the molten alloy, and the spalling of face coat shell during casting.

(3) For the major elements of $\mathrm{Al}, \mathrm{Nb}$ and $\mathrm{Cr}$, the composition difference between the top and the bottom of the castings is less than that of the ingots, but the trend is opposite for the $\mathrm{O}$ element, indicating that the investment casting is a homogenization process for $\mathrm{Cr}$ and $\mathrm{Nb}$, but a differentiation process for $\mathrm{O}$.

(4) The content variation of major elements ( $\mathrm{Al}, \mathrm{Nb}$ and $\mathrm{Cr}$ ) in different castings is mainly in the range of that corresponding ingots, which indicates that the investment casting is controllable for contents of the major elements.

\section{Acknowledgements}

This research was financially supported by the National Natural Science Foundation of China (Grant No. 51671026) and the State Key Lab of Advanced Metals and Materials, China (Grant No. 2019-ZD05).

\section{References}

[1] Kim Y W, Kim S L. Advances in Gammalloy materialsprocesses-application technology: successes, dilemmas, and future. JOM, 2018, 70(4): 553-560.

[2] Clemens H, Mayer S. Design, processing, microstructure, properties, and applications of advanced intermetallic TiAl alloys. Advanced Engineering Materials, 2013, 15(4): 191-215.

[3] Hu D W, Wu X H, Loretto M H. Advances in optimisation of mechanical properties in cast TiAl alloys. Intermetallics, 2005, 13(9): 914-919.

[4] Güther V, Klose J, Allen M, et al. Metallurgical processing of titanium aluminides on industrial scale. Intermetallics, 2018, 103: $12-22$
[5] Lapin J, Klimová A. Vacuum induction melting and casting of TiAl-based matrix in-situ composites reinforced by carbide particles using graphite crucibles and moulds. Vacuum, 2019, 169: 108930

[6] Su Y Q, Guo J J, Jia J, et al. Composition control of a TiAl melt during the induction skull melting (ISM) process. Journal of Alloys \& Compounds, 2002, 334: 261-266.

[7] Hu D W. Effect of composition on grain refinement in TiAlbased alloys. Intermetallics, 2001, 9: 1037-1043.

[8] Xu X J, Lin J P, Wang $Y L$, et al. Effect of forging on microstructure and tensile properties of Ti-45Al-(8-9) Nb- (W, B, Y) alloy. Journal of Alloys \& Compounds, 2006, 414(1-2): 175-180.

[9] Chen G L, Xu X J, Teng $Z$ K, et al. Microsegregation in high $\mathrm{Nb}$ containing TiAl alloy ingots beyond laboratory scale. Intermetallics, 2007, 15(5-6): 625-631.

[10] Zhao J, Zhang Z Y, Liu S B, et al. Elimination of misrun and gas hole defects of investment casting TiAl alloy turbocharger based on numerical simulation and experimental study. China Foundry, 2020, 17(1): 29-34.

[11] Daloz D, Hecht U, Zollinger J, et al. Microsegregation, macrosegregation and related phase transformations in TiAl alloys. Intermetallics, 2011, 19(6): 749-756.

[12] Recina V, Lundstrom V, Karlsson B. Tensile, creep, and lowcycle fatigue behavior of a cast $\mathrm{Y}$-TiAl-based alloy for gas turbine applications. Metallugical \& Materials Transactions A, 2002, 33: 2869-2881.

[13] Cui R J, Tang X X, Gao M, et al. Microstructure and composition of cast Ti-47Al-2Cr-2Nb alloys produced by yttria crucibles. Materials Science and Engineering: A, 2012, 541: 14-21.

[14] Sun H L, Zhang Z W, Zhu D G, et al. Dendrite core grain refining and interdendritic coarsening behaviour in $\mathrm{W}$-containing $\mathrm{Y}$-TiAl based alloys. Journal of Alloys \& Compounds, 2013, 552: 213-218.

[15] Kuang J P, Harding R A, Campbell J. Microstructures and properties of investment castings of $\mathrm{Y}$-titanium aluminide. Materials Science and Engineering: A, 2002, 329: 31-37.

[16] Huang Z W. Inhomogeneous microstructure in highly alloyed cast TiAl-based alloys, caused by microsegregation. Scripta Materialia, 2005, 52(10): 1021-1025.

[17] Tetsui T, Kobayashi T, Ueno T, et al. Consideration of the influence of contamination from oxide crucibles on TiAl cast material, and the possibility of achieving low-purity TiAl precision cast turbine wheels. Intermetallics, 2012, 31: 274-281. 